\title{
ACTH-receptor expression, regulation and role in adrenocortical tumor formation
}

\author{
Felix Beuschlein, Martin Fassnacht ${ }^{1}$, Albrecht Klink, Bruno Allolio ${ }^{1}$ and Martin Reincke \\ Schwerpunkt Endokrinologie, Abteilung Innere Medizin II, Klinikum der Albert-Ludwigs-Universität, Freiburg, Germany and \\ ${ }^{1}$ Schwerpunkt Endokrinologie, Diabetologie und Rheumatologie, Medizinische Universitätsklinik, Würzburg, Germany \\ (Correspondence should be addressed to M Reincke, Abteilung Innere Medizin II, Klinikum der Albert-Ludwigs-Universität Freiburg, Hugstetter Str. 55, \\ 79111 Freiburg, Germany; Email: reincke@med1.ukl.uni-freiburg.de)
}

\section{Introduction}

The production of adrenal glucocorticoids and androgens from the zona fasciculata and reticularis is predominantly regulated by adrenocorticotropin (ACTH) (1). Moreover, this 39-amino acid peptide derived from pituitary proopiomelanocortin contributes to the short-term secretion of mineralocorticoids from the zona glomerulosa (2). ACTH acts via a seventransmembrane domain receptor belonging to the G-protein-coupled receptor superfamily leading to activation of the adenylate cyclase pathway and consecutive activation of protein kinase A (3). Activation of other signal-transduction cascades by ACTH, such as the protein kinase $C(4-6)$ and the lipooxygenase pathway (7), has also been described. After long-term stimulation, ACTH increases the output of adrenal fasciculata cells by increasing the expression of several key steroidogenic enzymes (8). Additionally, ACTH is crucial for the development of the adrenal cortex and may play an essential part in adaptational processes like adrenal hypertrophy (9). The ACTH receptor is mainly expressed in the adrenal cortex, but has been identified in human skin (10), in an ovarian steroid cell tumor (11) and in rodent adipocytes (12). There is no evidence of ACTH-receptor expression in other tissues, implying that an effective mechanism exists to restrict expression of this gene.

\section{Genomic organization}

Substantial progress in the understanding of the expression and regulation of the ACTH receptor has been made since the cloning of the ACTH-receptor gene by the group of Cone in 1992 (13). The coding sequence of the human ACTH receptor contains no intron, but the presence of one intron (of about $18 \mathrm{~kb}$ ) separating the coding exon 2 from an upstream untranslated exon 1 has been demonstrated. The major transcription start site is located in the second exon. Northern blot analysis of cultured human adrenocortical cells revealed several transcripts that can be partly explained by the use of different initiation sites of transcription (14). The genomic organization of the ACTH receptor is shown in Fig. 1. One kilobase of the promoter region of the ACTH receptor has been cloned and the presence of several putative binding sites for transcriptional factors has been reported (15) (Fig. 2).

The ACTH receptor is a member of the superfamily of G-protein-coupled receptors with seven transmembrane domains (16). Together with several melanotropin receptors, the ACTH receptor belongs to the melanocortin receptor subfamily. Those receptors are characterized by short $\mathrm{NH}_{2}$-terminal extracellular domains, short intracellular $\mathrm{COOH}$-terminal domains as well as short fourth and fifth transmembranespanning domains (16). Up to now, the ACTH receptor is the shortest known G-protein-coupled receptor, consisting of 297 residues with a predicted molecular mass of $33 \mathrm{kDa}$. Two putative glycosylation sites are part of the $\mathrm{NH}_{2}$-terminus of the ACTH receptor. Thus, glycosylation may account for the molecular mass of $43 \mathrm{kDa}$, which has been inferred by cross-linking experiments (17). Since no antibody against the human ACTH receptor is available to date, detailed experiments at the protein level are still hampered.

\section{ACTH-receptor promoter and regulation of expression}

Already prior to cloning of the ACTH receptor it has been demonstrated that the expression of ACTHbinding sites on human adrenocortical cells is upregulated after exposure of the cells to ACTH (18). This unusual up-regulation by its own ligand was confirmed in recent studies showing up-regulation of ACTHreceptor mRNA and receptor-binding sites in human adrenocortical cells after stimulation with ACTH (19). In addition, up-regulation of ACTH-receptor expression by angiotensin II has been reported, probably through pathways not involving protein kinase A $(19,20)$. ACTH not only increases the transcriptional rate of ACTH-receptor message but also prolongs the ACTHreceptor mRNA half-life (21). In addition, the number of ACTH-binding sites is also up-regulated by other activators of the cAMP pathway like dbcAMP and forskolin (20). These findings could explain why adrenal responsiveness to ACTH is impaired rapidly after suppression of endogenous ACTH and restored within hours in patients with secondary adrenal insufficiency exposed to i.v. administered exogenous 


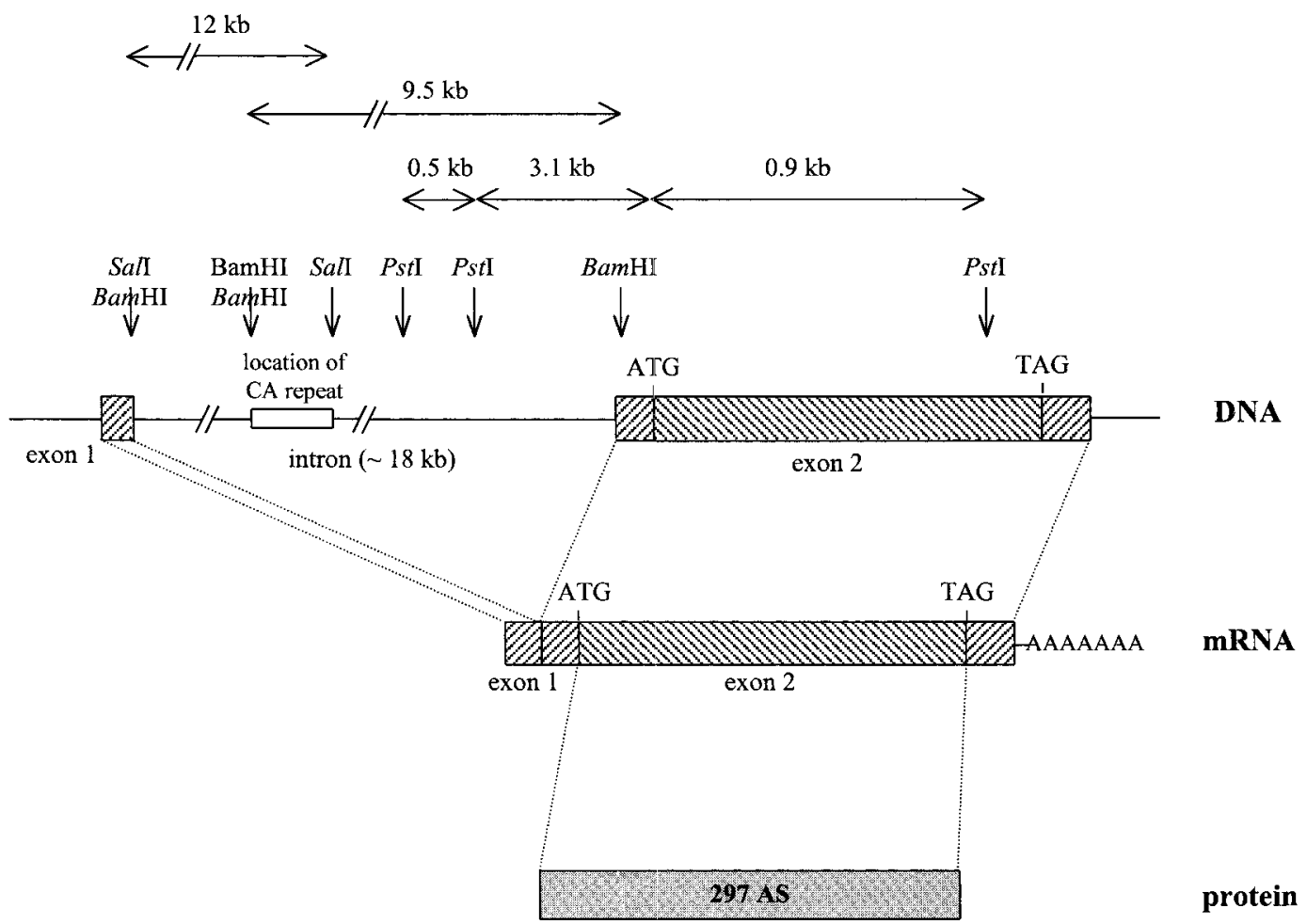

Figure 1 Diagrammatic representation of the proposed genomic structure of the ACTH-receptor gene and the mature mRNA transcript and protein. Pstl indicates restriction sites for Pstl-restriction polymorphism; CA repeat indicates the interval between $12 \mathrm{~kb}$ Sacl and $9.5 \mathrm{~kb} \mathrm{BamHl}$ fragment, where the highly polymorphic marker within the intron of the ACTH receptor is located. Adapted from (15) and (58). AS, amino acids.

ACTH (22). The effects of ACTH on ACTH-receptor expression are mediated through the cAMP signaltransduction pathway because they can be mimicked by treatment with forskolin and cAMP itself. Accordingly, several putative cAMP-responding elements have been identified in the promoter of the human ACTHreceptor gene, suggesting direct stimulation of ACTHreceptor gene transcription by cAMP (15). By deletion analysis the region between -764 and -503 of the promoter was shown to confer cAMP responsiveness, which was abolished after mutation of an AP-1 site (23). This indicates that cAMP responsiveness of the human ACTH-receptor promoter is mediated by AP-1 (Fig. 2).

Steroidogenic factor 1 (SF-1) is an orphan nuclear receptor which regulates several genes involved in steroidogenesis (24) and is a development regulator critical for the formation of adrenals and gonads (25). SF-1 seems to play a pivotal role in determining the tissue-specific expression of its target genes. The presence of three SF-1-binding sites has been demonstrated in the ACTH-receptor promoter at position $-35,-98$ and -209 bp (26-28). The SF-1 element at $-35 \mathrm{bp}$ is reported to be involved in the basal promoter activity but is not sufficient for the cAMP-regulated expression of the ACTH-receptor gene (29). Mutation in all three binding sites led to a marked decrease of promoter activity. Only the SF-1 elements at position $-35 \mathrm{bp}$ and $-98 \mathrm{bp}$ but not the $-209 \mathrm{bp}$ element seem to be major contributors to the forskolinstimulated promoter activity (26).

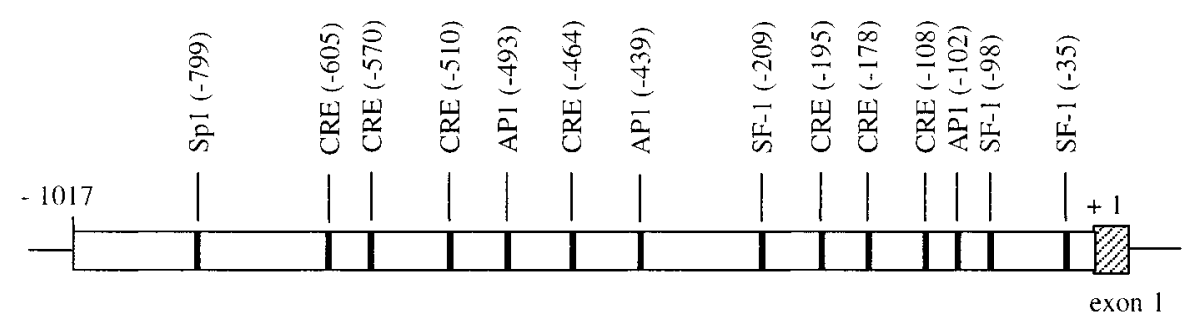

Figure 2 Structure of the ACTH-receptor promoter region. Relative position of putative regulatory elements are shown. For details see text. 


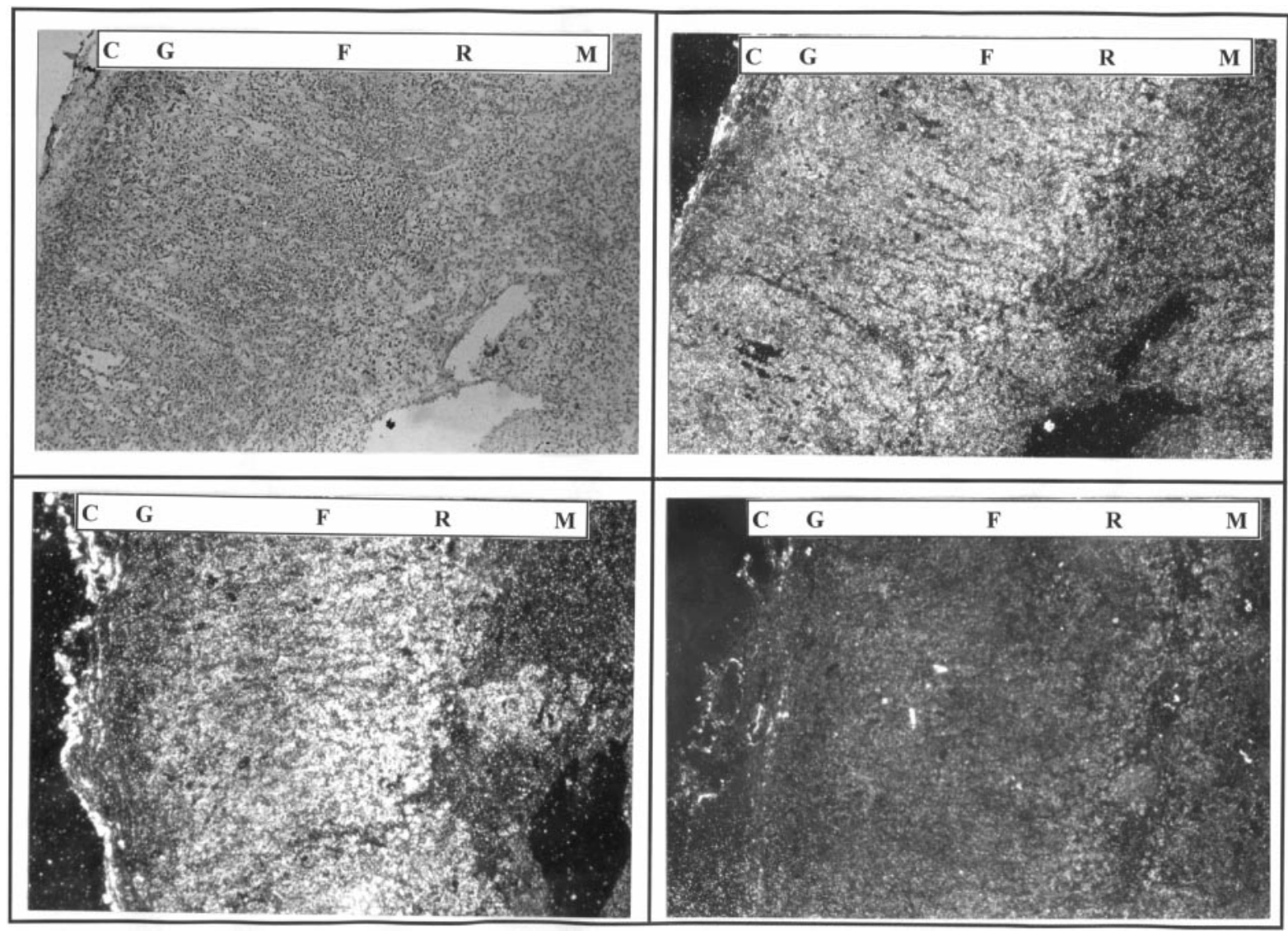

Figure 3 Localization of ACTH-receptor mRNA in human adrenal cortex by in situ hybridization. Upper left: bright-field microscopy ( $\times 50)$. Upper right: dark-field microscopy $(\times 50)$ shows the presence of specific mRNA indicated by white staining. Intense mRNA accumulation is present in the zona glomerulosa $(G)$, the zona fasciculata $(F)$ and the zona reticularis $(R)$, but not in the capsule $(C)$ and the medulla $(M)$ of the adrenal gland. Lower left: P450 17-hydroxylase mRNA expression of the same adrenal slice with absent mRNA in the zona glomerulosa and high mRNA expression in the zona fasciculata and in the zona reticularis. Lower right: control section hybridized with the ACTHreceptor cDNA after RNAse pretreatment. Magnification $\times 50$. Reproduced from (41) by permission of the Journal of Endocrinology Ltd.

Conversely, ACTH-receptor expression can be suppressed by adrenal-specific transcription factors, like DAX-1 (dosage-sensitive sex reversal adrenal hypoplasia congenita critical region on the $\mathrm{X}$ chromosome gene 1). DAX-1 is a repressor of several P450 enzymes in the adrenal gland and has been shown to act by multiple mechanisms (30). We investigated ACTH-receptor gene regulation by DAX-1 using the mouse Y1 tumor cell line transfected with the human ACTH-receptor promoter coupled to a luciferase reporter gene. Coexpression of DAX-1 clearly reduced basal and forskolin-stimulated gene expression. The effect of DAX-1 appears to be mediated by interaction with SF-1, as elimination of the SF-1 binding site in the ACTHreceptor promoter by site-directed mutagenesis abolished its suppressive action (27). Further evidence for a suppressive effect of DAX-1 comes from adrenocortical tumor tissues: DAX-1 and ACTH-receptor mRNAs show a negative correlation in adrenocortical tumors supporting an in vivo effect of DAX-1 on the ACTH-receptor promoter (31).
It has been reported that glucocorticoids enhance the ACTH-induced cAMP or cortisol response in adrenal cells or guinea pig adrenal glands (32-34). This effect was hypothesized to be mediated by up-regulation of ACTH-receptor expression by glucocorticoids. Recently, stimulation of ACTH-receptor mRNA by glucocorticoids has been demonstrated in a time- and dose-dependent manner (35). This enhancing effect was specific for glucocorticoids because the anti-glucocorticoid RU486 blocked the effect of dexamethasone, whereas other steroids such as testosterone did not modify ACTHreceptor mRNA levels.

Conversely, down-regulation of ACTH-receptor mRNA in vivo has been shown in rats treated with i.p. dexamethasone leading to suppressed plasma ACTH levels (36). Similarly, ACTH-receptor mRNA expression was low in a knockout mouse model with a deleted proopiomelanocortin promoter, which led to low plasma ACTH levels (37). Treatment of the human adrenocortical tumor cell line NCI-h295 with the adrenostatic compounds aminoglutethimide and 


\section{ACTH-R}

P450sce

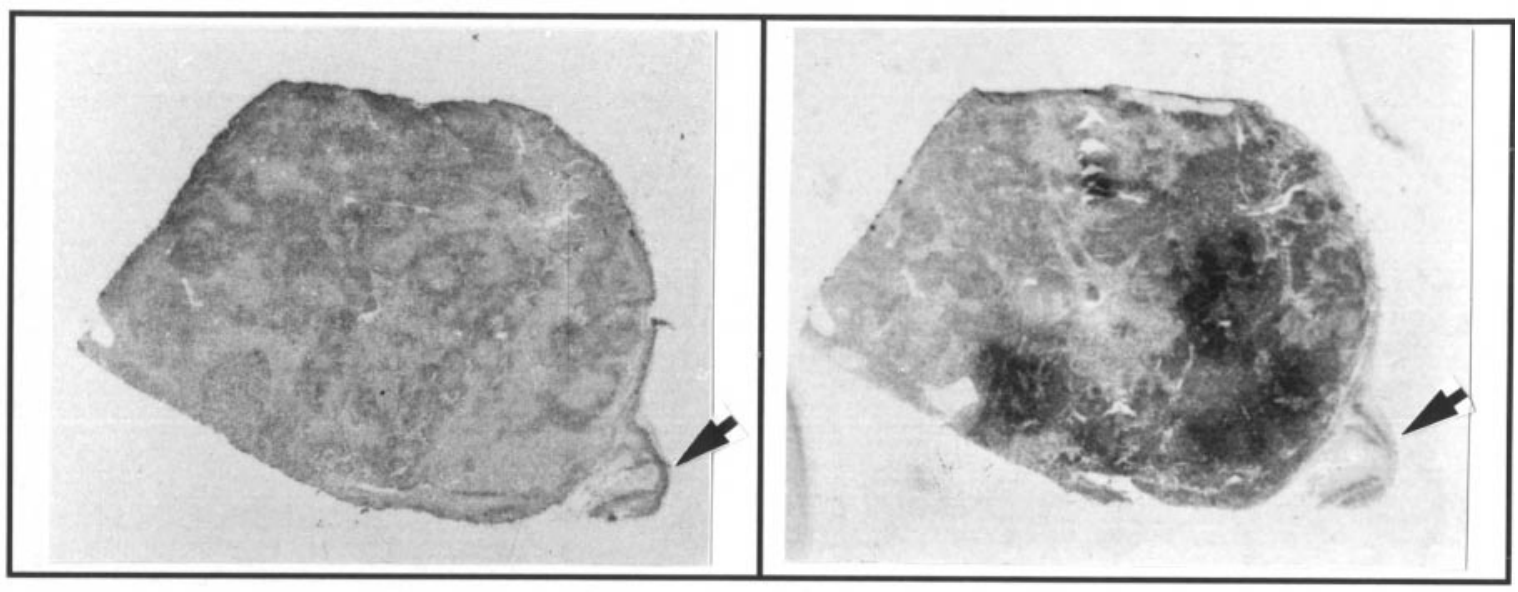

P450c17

+RNase

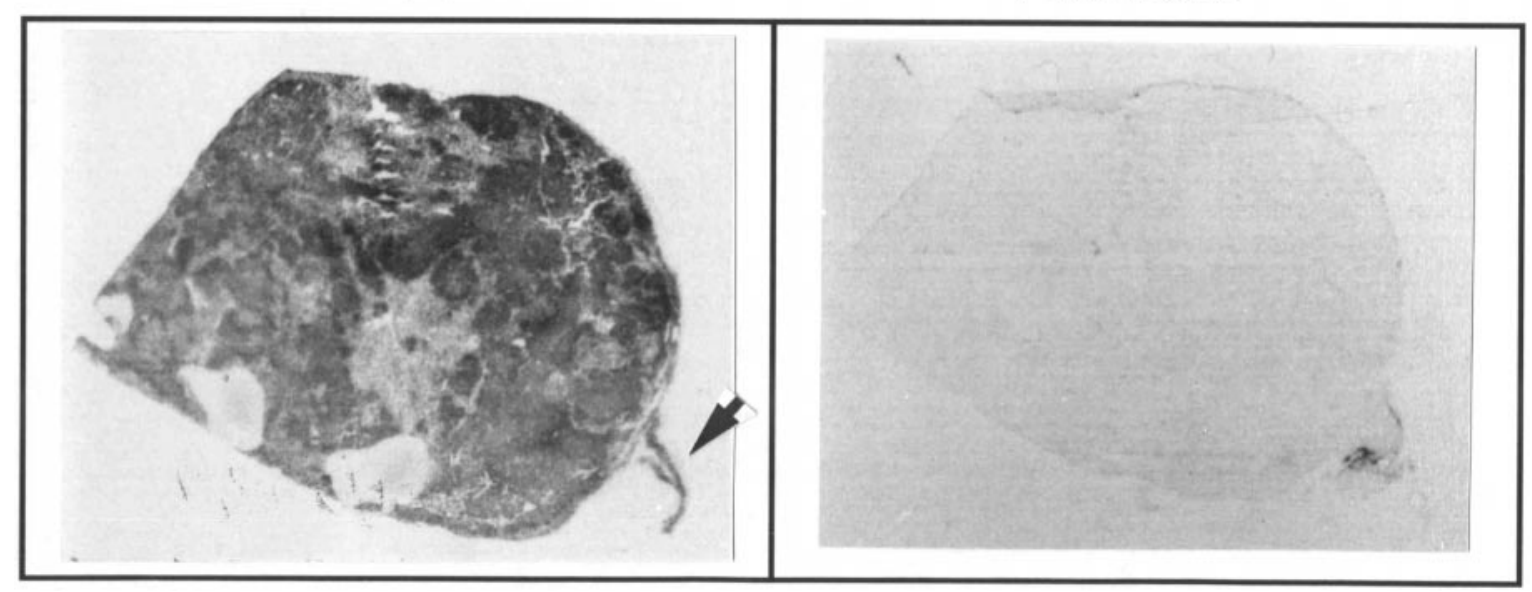

Figure 4 In situ hybridization of the ACTH-receptor (ACTH-R) mRNA, P450 side chain cleavage enzyme (P450scc) mRNA, and P450 17hydroxylase (P450c17) mRNA in an aldosterone-producing adenoma. Control sections (+RNAse) were pretreated with RNAse before incubation with the ACTH-receptor cDNA. The adjacent normal adrenal cortex is visible on the right (arrow). Magnification $\times 5$. Reproduced from (41) by permission of the Journal of Endocrinology Ltd.

metyrapone led to down-regulation of ACTH-receptor mRNA $(35,38)$. This effect can be reversed by stimulation of the cAMP pathway and of the glucocorticoid-mediated signal-transduction cascade.

\section{In vivo ACTH-receptor expression}

The adrenal cortex is composed of three distinct zones with different morphological and functional characteristics: the zona glomerulosa, which secretes mainly mineralocorticoids, the glucocorticoid-producing zona fasciculata, and the innermost zona reticularis, which is the source of adrenal androgens. The physiology of steroid secretion suggests expression of the ACTH receptor in all three zones, since acute administration of ACTH leads to enhanced secretion of mineralocorticoids, glucocorticoids and androgens $(39,40)$. In accord with this notion, ACTH-receptor mRNA was detected in all three adrenocortical zones by means of in situ hybridization (41) (Fig. 3). In mice, ACTH-receptor mRNA expression was found mainly in the zona glomerulosa and the zona fasciculata, whereas cells of the zona reticularis expressed ACTH-receptor mRNA to a lesser degree (42). Similar distribution of ACTHreceptor mRNA was found in normal bovine adrenal cortex with a more abundant expression in zona glomerulosa than in zona fasciculata and reticularis cells (43).

Possible involvement of ACTH-receptor expression in adrenocortical development was underlined in recent studies of in situ hybridization experiments in human (44) and baboon fetuses (45). In human fetal adrenal 
tissue from midgestation, mRNA encoding the ACTH receptor was localized in cells from all cortical zones, with higher abundance in the definite zone (which corresponds to the zona glomerulosa) compared with the fetal zone (reflecting the zona reticularis). In the baboon fetal adrenal gland, a biphasic developmental expression of ACTH receptor was reported with the lowest expression in early gestation, high expression in midgestation and a decline of ACTH-receptor mRNA in late gestation respectively. Because the fetal adrenal is comprised mainly of the fetal cortical zone throughout gestation, the decrease in ACTH-receptor expression between mid- and late gestation seems to occur primarily in the latter zone and may signal a selective decline in tropic responsiveness of androgen biosynthesis within the baboon fetal adrenal gland.

\section{ACTH-receptor localization and expression in adrenal tumors and cell lines}

\section{ACTH-receptor mRNA expression in tumor tissue}

Aldosterone- and glucocorticoid-producing adrenocortical adenomas are responsive to ACTH in vivo and in vitro, suggesting the expression of functional ACTH receptors $(46,47)$. In accord with this notion, we found high ACTH-receptor mRNA expression using Northern blotting and in situ hybridization in cortisol-producing and aldosterone-producing adenomas, whereas nonfunctional adenomas and carcinomas had low or absent ACTH-receptor mRNA levels (31) (Fig. 4). An overexpression of ACTH-receptor mRNA in aldosterone-producing adenomas was confirmed by findings of Arnaldi et al. (48). This finding supports the role of ACTH on aldosterone secretion as suggested by the presence of a diurnal rhythm. In a case of virilizing adrenocortical adenoma, ACTH-receptor mRNA was not detected and ACTH did not increase the in vitro production of androgens (49). Taken together, plasma ACTH concentrations seem to have no major influence on ACTH-receptor mRNA in hyperplastic and neoplastic adrenal tissue because ACTH mRNA levels were neither increased in adrenal hyperplasia due to Cushing's disease nor reduced in adrenal Cushing's syndrome with suppressed plasma ACTH.

\section{ACTH-receptor modulation by adrenostatic compounds}

Modulation of ACTH-receptor expression may be desirable in patients with adrenal pathology. The adrenostatic compound aminoglutethimide, a potent inhibitor of the P450 side chain cleavage enzyme, has been shown to inhibit ACTH-receptor mRNA expression in ovine adrenocortical cells in a time-dependent fashion (33). We recently investigated whether aminoglutethimide suppresses ACTH-receptor expression in the NCI-h295 adrenocortical carcinoma cell line, which expresses functional ACTH receptors and produces steroids of the glucocorticoid, mineralocorticoid and androgen pathways (38). Aminoglutethimide significantly suppressed baseline ACTH-receptor mRNA expression in a dose-dependent fashion. This was paralleled by low ACTH-induced cAMP accumulation, indicating reduced expression of ACTH-receptor protein. The adrenostatic compound metyrapone, an inhibitor of $11 \beta$-hydroxylase activity, also suppressed ACTHreceptor mRNA expression in a similar manner. These data show that aminoglutethimide and metyrapone induce profound ACTH-receptor down-regulation in the NCI-h295 cell line by as yet undefined mechanisms. Because the down-regulation occurs in vitro at concentrations that are reached during treatment with aminoglutethimide in vivo it may contribute to the therapeutic activity of adrenostatic compounds in adrenal disease.

\section{ACTH-receptor mutations in adrenal tumors}

\section{No evidence for activating point mutations}

cAMP is a key second messenger involved in hormone hypersecretion and/or increased cell proliferation in many endocrine tissues. Activating mutations of cAMP-regulating proteins, such as G-protein-coupled receptors and GTP-binding proteins have been implicated in a variety of human disorders including acromegaly and toxic thyroid adenomas (50, 51). Oncogenic transformation of the thyrotropin-receptor gene by point mutations was found in approximately $30 \%$ of hyperfunctioning thyroid adenomas (51). The mutant receptors conferred constitutive activation of adenylate cyclase after in vitro transfection experiments. An alternative pathway increasing intracellular cAMP levels also associated with tumorigenesis is constitutive activating mutations in the $\alpha$-chain of the stimulatory G-protein (Gs) found in growth hormone-producing adenomas and thyroid adenomas (51).

Adrenocortical tumorigenesis differs from pituitary and thyroid tumorigenesis because activation of the $\mathrm{cAMP} /$ protein kinase A pathway seems to be of little importance in the development of adrenocortical neoplasms. Although ACTH stimulates adrenal synthesis of steroidogenic enzymes, leading to increased steroid production and an increase in adrenal weight, a proliferative activity of ACTH has been questioned. Physiological ACTH levels are unable to induce compensatory adrenal hyperplasia after unilateral adrenalectomy in hypophysectomized animals (52). In vitro, inhibition of adrenal cell proliferation by physiological ACTH concentrations has been reported, and 
even pharmacological doses of ACTH induce only moderate cell growth (53). In accord with this findings, activating point mutations of neither the ACTH receptor nor the $\alpha$-chain of Gs have been identified in benign or malignant adrenocortical tumors $(50,54-56)$. On the contrary, activating mutations of the Gi2, one of the adenylyl cyclase inhibitory G-proteins, were found in a minority of adrenocortical tumors $(50,56,57)$.

These data suggest that, in the adrenal cortex, the ACTH/G-protein kinase A signaling pathway is preferentially important for regulation of steroid hormone secretion and, hence, maintenance of a highly differentiated cellular phenotype while it seems to be of low importance for cellular proliferation.

\section{Loss of constitutive heterozygosity (LOH) of the ACTH-receptor gene locus}

Beside point mutations, loss or impairment of function of the ACTH-receptor gene could be caused by deletion of the ACTH-receptor gene locus. Recently, we identified a PstI polymorphism in the promoter region of the ACTH-receptor gene (58) (Fig. 1). The rate of heterozygosity for this polymorphism was $53.3 \%$. In a series of 20 cases with benign and malignant adrenocortical tumors, LOH of the ACTH-receptor gene was associated with an advanced tumor stage and a more rapid course than in carcinoma patients without LOH. Northern blot experiments demonstrated reduced expression of ACTH-receptor mRNA in the tumors with $\mathrm{LOH}$ of the ACTH-receptor gene, suggesting functional significance of the finding at the transcriptional level.

In a recent approach, we discovered a highly polymorphic marker lying $9.5 \mathrm{~kb}$ to $6.0 \mathrm{~kb}$ upstream of the ACTH receptor coding exon 2, within the intron of the ACTH-receptor gene (Fig. 1). Using this novel microsatellite marker with $17 \mathrm{CA}$ repeats a rate of heterozygosity of $>98 \%$ could be obtained in 66 investigated individuals. LOH of the ACTH-receptor gene locus was found in 5 out of 13 carcinoma patients $(38 \%)$, but in none of 30 adrenal adenomas, 9 pheochromocytomas or 14 other adrenal masses (59).

These data suggest that the ACTH receptor may act as a tumor-suppressor gene. Allelic loss of the ACTHreceptor gene in adrenocortical tumors can result in loss of differentiation, a characteristic feature of human tumorigenesis that is associated with clonal expansion of a malignant cell clone.

\section{Summary}

The regulation of the ACTH-receptor gene is unique in that it is up-regulated by its own ligand, ACTH. Ligandinduced up-regulation of ACTH-receptor expression may be an important adaptive process directed towards optimizing adrenal responsiveness to ACTH in the context of physiological stress and the maintenance of metabolic homeostasis in which the adrenals play a pivotal role. Whereas enhancement by ligand-induced up-regulation permits a more efficient and rapid glucocorticoid response, negative feedback regulation of glucocorticoids in the hypothalamus and pituitary inhibits ACTH secretion and allows a balanced adrenal response to stress. Since the cloning of the promoter region of the ACTH receptor, considerable progress in the understanding of the regulatory processes has been made. The effects of ACTH on ACTH-receptor expression is dependent on cAMP, probably mediated through AP-1. The profound effect of three SF-1-binding sites in the ACTH-receptor promoter was demonstrated by deletion experiments. Conversely, ACTH-receptor expression can be suppressed by adrenal-specific transcription factors, like DAX-1.

Despite an extensive search, no activating ACTHreceptor mutations have been found in adrenal tumors, excluding the ACTH receptor as a relevant oncogene in adrenal tumorigenesis. However, the ACTH receptor may act as a differentiation factor as suggested by $\mathrm{LOH}$ in adrenal carcinomas with an undifferentiated tumor type. In benign adrenal tumors, a strong correlation between ACTH-receptor expression and expression of $\mathrm{P} 450$ steroidogenic enzymes is evident. This close regulative relationship is lost in adrenal carcinoma, probably as a result of tumor dedifferentiation. Down-regulation of ACTH-receptor expression in normal and neoplastic tissue can be achieved by adrenostatic compounds such as aminoglutethimide and metyrapone.

\section{Acknowledgements}

This work was supported by the Mildred Scheel-Stiftung and the Deutsche Forschungsgemeinschaft.

\section{References}

1 Gill GN. ACTH regulation of the adrenal cortex. In Pharmacology of Adrenal Cortical Hormones, pp 35-39. Eds GN Gill. New York: Pergamon, 1979.

2 Aguilera G. Factors controlling steroid biosynthesis in the zona glomerulosa of the adrenal. Journal of Steroid Biochemistry and Molecular Biology $1993 \mathbf{4 5} 147-151$.

3 Buckley DI \& Ramachandran J. Characterization of corticotropin receptors on adrenocortical cells. PNAS $1981787431-7435$.

4 Arola J, Heikkila P, Voutilainen R \& Kahri AI. Protein kinase C signal transduction pathway in ACTH-induced growth effect of rat adrenocortical cells in primary culture. Journal of Endocrinology $1994141285-293$.

5 Armelin HA, Lotfi CF \& Lepique AP. Regulation of growth by ACTH in the Y-1 line of mouse adrenocortical cells. Endocrine Research 199622 373-383.

6 Parissenti AM, Kirwan AF, Kim SA, Colantonio CM \& Schimmer BP. Molecular strategies for the dominant inhibition of protein kinase C. Endocrine Research 199622 621-630.

7 Yamazaki T, Higuchi K, Kominami S \& Takemori S. 15Lipoxygenase metabolite(s) of arachidonic acid mediates adrenocorticotropin action in bovine adrenal steroidogenesis. Endocrinology $1996 \mathbf{1 3 7} 2670-2675$.

8 Simpson ER \& Waterman MR. Regulation of the synthesis of steroidogenic enzymes in adrenal cortical cells by ACTH. Annual Review of Physiology $1988 \mathbf{5 0} 427-440$. 
9 Baxter JD \& Tyrrel JD. The adrenal cortex. In Endocrinology and Metabolism, edn 2, pp 511-692. Eds P Felig, JD Baxter, AE Broadus \& LA Frohman. New York: McGraw-Hill, 1986.

10 Slominski A, Ermak G \& Mihm M. ACTH receptor, CYP11A1, CYP17 and CYP21A2 genes are expressed in skin. Journal of Clinical Endocrinology and Metabolism 199681 2746-2749.

11 Lin CJ, Jorge AA, Latronico AC, Marui S, Fragoso MC, Martin RM et al. Origin of an ovarian steroid cell tumor causing isosexual pseudoprecocious puberty demonstrated by the expression of adrenal steroidogenic enzymes and adrenocorticotropin receptor. Journal of Clinical Endocrinology and Metabolism 2000851211 1214.

12 Boston BA \& Cone RD. Characterization of melanocortin receptor subtype expression in murine adipose tissues and in the 3T3-L1 cell line. Endocrinology 1996137 2043-2050.

13 Mountjoy KG, Robbins LS, Mortrud MT \& Cone RD. The cloning of a family of genes that encode the melanocortin receptors. Science 1992257 1248-1251.

14 Naville D, Penhoat A, Barjhoux L, Jaillard C, Fontanay S, Saez J et al. Characterization of the human ACTH receptor gene and in vitro expression. Endocrine Research 199622 337-348.

15 Naville D, Jaillard C, Barjhoux L, Durand P \& Begeot M. Genomic structure and promoter characterization of the human ACTH receptor gene. Biochemical and Biophysical Research Communications $19972307-12$.

16 Cone RD, Mountjoy KG, Robbins LS, Nadeau JH, Johnson KR, Roselli-Rehfuss L et al. Cloning and functional characterization of a family of receptors for the melanotropic peptides. Annals of the New York Academy of Sciences $1993 \mathbf{6 8 0} 342-363$.

17 Penhoat A, Jaillard C \& Saez JM. Identification and characterization of corticotropin receptors in bovine and human adrenals. Journal of Steroid Biochemistry and Molecular Biology $1993 \mathbf{4 4}$ 21-27.

18 Penhoat A, Jaillard C \& Saez JM. Corticotropin positively regulates its own receptors and cAMP response in cultured bovine adrenal cells. PNAS 198986 4978-4981.

19 Lebrethon MC, Naville D, Begeot M \& Saez JM. Regulation of corticotropin receptor number and messenger RNA in cultured human adrenocortical cells by corticotropin and angiotensin II. Journal of Clinical Investigation 199493 1828-1833.

20 Mountjoy KG, Bird IM, Rainey WE \& Cone RD. ACTH induces upregulation of ACTH receptor mRNA in mouse and human adrenocortical cell lines. Molecular and Cellular Endocrinology 199499 R17-R20.

21 Penhoat A, Jaillard C, Begeot M, Durand P \& Saez JM. Cycloheximide enhances ACTH-receptor mRNA through transcriptional and post-transcriptional mechanisms in bovine adrenocortical cells. Molecular and Cellular Endocrinology 1996 $12157-63$.

22 Avgerinos PC, Schurmeyer TH, Gold PW, Tomai TP, Loriaux DL, Sherins RJ et al. Pulsatile administration of human corticotropinreleasing hormone in patients with secondary adrenal insufficiency: restoration of the normal cortisol secretory pattern. Journal of Clinical Endocrinology and Metabolism $1986 \mathbf{6 2} 816$ 821.

23 Sarkar D, Kambe F, Hayashi Y, Ohmori S, Funahashi H \& Seo H. Involvement of AP-1 and sterodogenic factor-1 in cAMP mediated induction of human adrenocorticotropin hormone receptor gene. In Program and Abstracts of The Endocrine Society Meeting, San Diego, CA, USA, 12-15 June 1999, P2-328. Bethesda, MD, USA: The Endocrine Society Press.

24 Lala DS, Ikeda Y, Luo X, Baity LA, Meade JC \& Parker KL. A cellspecific nuclear receptor regulates the steroid hydroxylases. Steroids $19956010-14$.

25 Hammer GD \& Ingraham HA. Steroidogenic factor-1: its role in endocrine organ development and differentiation. Frontiers in Neuroendocrinology 199920 199-223.

26 Naville D, Penhoat A, Durand P \& Begeot M. Three steroidogenic factor-1 binding elements are required for constitutive and cAMP-regulated expression of the human adrenocorticotropin receptor gene. Biochemical and Biophysical Research Communications $199925528-33$.

27 Klink A, Lalli E, Sassone-Corsi P \& Reincke M. DAX-1 and SF-1 both cooperate and have antagonistic effects in the expression of the human ACTH receptor. In Program and Abstracts of the Endocrine Society Meeting, San Diego, CA, USA, 12-15 June 1999, P3-404. Bethesda, MD, USA: The Endocrine Society Press.

28 Sarkar D, Kambe F, Hayashi Y \& Seo H. Characterization of 5'regulatory region of the human ACTH receptor gene: role of steroidogenic factor 1 in tissue specific expression. In Program and Abstracts of The Endocrine Society Meeting, New Orleans, LA, USA, 24-27 June 1998, P1-43. Bethesda, MD, USA: The Endocrine Society Press.

29 Marchal R, Naville D, Durand P, Begeot M \& Penhoat A. A steroidogenic factor-1 binding element is essential for basal human ACTH receptor gene transcription. Biochemical and Biophysical Research Communications 1998247 28-32.

30 Lalli E, Melner MH, Stocco DM \& Sassone-Corsi P. DAX-1 blocks steroid production at multiple levels. Endocrinology 1998139 4237-4243.

31 Reincke M, Beuschlein F, Lalli E, Arlt W, Vay S, Sassone-Corsi P et al. DAX-1 expression in human adrenocortical neoplasms: implications for steroidogenesis. Journal of Clinical Endocrinology and Metabolism 199883 2597-2600.

32 Darbeida H \& Durand P. Glucocorticoid enhancement of adrenocorticotropin-induced $3^{\prime}, 5^{\prime}$-cyclic adenosine monophosphate production by cultured ovine adrenocortical cells. Endocrinology 1987121 1051-1055.

33 Darbeida H \& Durand P. Mechanism of glucocorticoid enhancement of the responsiveness of ovine adrenocortical cells to adrenocorticotropin. Biochemical and Biophysical Research Communications $19901661183-1191$.

34 Mokuda O, Ubukata E \& Sakamoto Y. Glucocorticoids potentiate effect of ACTH on cortisol secretion in isolated perfused guinea pig adrenal glands. Experimental and Clinical Endocrinology and Diabetes 1997105 119-121.

35 Picard-Hagen N, Penhoat A, Hue D, Jaillard C \& Durand P. Glucocorticoids enhance corticotropin receptor mRNA levels in ovine adrenocortical cells. Journal of Molecular Endocrinology $19971929-36$.

36 Morita TM, Imai T, Murata Y, Kambe F, Funahashi H, Takagi H et al. Adrenocorticotropic hormone (ACTH) increases the expression of its own receptor gene. Endocrine Journal $1995 \mathbf{4 2}$ $475-480$.

37 Allen RG, Carey C, Parker JD, Mortrud MT, Mellon SH \& Low MJ. Targeted ablation of pituitary pre-proopiomelanocortin cells by herpes simplex virus-1 thymidine kinase differentially regulates mRNAs encoding the adrenocorticotropin receptor and aldosterone synthase in the mouse adrenal gland. Molecular Endocrinology 19959 1005-1016.

38 Fassnacht M, Beuschlein F, Vay S, Mora P, Allolio B \& Reincke M. Aminoglutethimide suppresses adrenocorticotropin receptor expression in the NCI-h295 adrenocortical tumor cell line. Journal of Endocrinology 1998159 35-42.

39 Kater CE, Biglieri EG, Brust N, Chang B, Hirai J \& Irony I. Stimulation and suppression of the mineralocorticoid hormones in normal subjects and adrenocortical disorders. Endocrine Reviews $198910149-164$.

40 Rosenfeld RS, Rosenberg BJ, Fukushima DK \& Hellman L. 24Hour secretory pattern of dehydroisoandrosterone and dehydroisoandrosterone sulfate. Journal of Clinical Endocrinology and Metabolism 197540 850-855.

41 Reincke M, Beuschlein F, Menig G, Hofmockel G, Arlt W, Lehmann $\mathrm{R}$ et al. Localization and expression of adrenocorticotropic hormone receptor mRNA in normal and neoplastic human adrenal cortex. Journal of Endocrinology $1998 \mathbf{1 5 6} 415-$ 423.

42 Xia Y \& Wikberg JES. Localization of ACTH receptor mRNA by in situ hybridization in mouse adrenal gland. Cell and Tissue Research 1996286 63-68. 
43 Liakos P, Chambaz EM, Feige JJ \& Defaye G. Expression of ACTH receptors (MC2-R and MC5-R) in the glomerulosa and the fasciculata-reticularis zones of bovine adrenal cortex. Endocrine Research $1998 \mathbf{2 4} 427-432$.

44 Mesiano S, Fujimoto VY, Nelson LR, Lee JY, Voytek CC \& Jaffe RB. Localization and regulation of corticotropin receptor expression in the midgestation human fetal adrenal cortex: implications for in utero homeostasis. Journal of Clinical Endocrinology and Metabolism 199681 340-345.

45 Albrecht ED, Aberdeen GW, Babischkin JS, Tilly JL \& Pepe GJ. Biphasic developmental expression of adrenocorticotropin receptor messenger ribonucleic acid levels in the baboon fetal adrenal gland. Endocrinology 1996137 1292-1298.

46 Ishizuka $\mathrm{T}$, Miura $\mathrm{K}$, Nagao $\mathrm{S}$ \& Nozawa $\mathrm{Y}$. Differential redistribution of protein kinase $\mathrm{C}$ in human aldosteronoma cells and adjacent adrenal cells stimulated with ACTH and angiotensin II. Biochemical and Biophysical Research Communications $1988155643-649$.

47 Kajita K, Ishizuka T, Yamamoto M, Nagashima T, Taniguchi O, Mune T et al. ACTH and phorbol ester stimulated redistribution of protein kinase $\mathrm{C}$ in human cortisol-producing adrenal adenoma. Endocrine Journal $1994 \mathbf{4 1} 107-113$.

48 Arnaldi G, Mancini V, Costantini C, Giovagnetti M, Petrelli M, Masini A et al. ACTH receptor mRNA in human adrenocortical tumors: overexpression in aldosteronomas. Endocrine Research $199824845-849$.

49 Imai T, Tobinaga J, Morita-Matsuyama T, Kikumori T, Sasano H, Seo $\mathrm{H}$ et al. Virilizing adrenocortical adenoma: in vitro steroidogenesis, immunohistochemical studies of steroidogenic enzymes, and gene expression of corticotropin receptor. Surgery $1999125396-402$.

50 Lyons J, Landis CA, Harsh G, Vallar L, Grunewald K, Feichtinger H et al. Two $\mathrm{G}$ protein oncogenes in human endocrine tumors. Science $1990249655-659$.

51 Parma J, Duprez L, Van Sande J, Cochaux P, Gervy C, Mockel J et al. Somatic mutations in the thyrotropin receptor gene cause hyperfunctioning thyroid adenomas. Nature $1993 \mathbf{3 6 5} 649-651$.

52 Dallman MF, Engeland WC, Holzwarth MA \& Scholz PM. Adrenocorticotropin inhibits compensatory adrenal growth after unilateral adrenalectomy. Endocrinology $19801071397-$ 1404.

53 Ramachandran J \& Suyama AT. Inhibition of replication of normal adrenocortical cells in culture by adrenocorticotropin. PNAS 197572 113-117.

54 Latronico AC, Reincke M, Mendonca BB, Arai K, Mora P, Allolio B et al. No evidence for oncogenic mutations in the adrenocorticotropin receptor gene in human adrenocortical neoplasms. Journal of Clinical Endocrinology and Metabolism $1995 \mathbf{8 0} 875-877$.

55 Light K, Jenkins PJ, Weber A, Perrett C, Grossman A, Pistorello M et al. Are activating mutations of the adrenocorticotropin receptor involved in adrenal cortical neoplasia? Life Sciences $1995561523-1527$.

56 Reincke M, Karl M, Travis W \& Chrousos GP. No evidence for oncogenic mutations in guanine nucleotide-binding proteins of human adrenocortical neoplasms. Journal of Clinical Endocrinology and Metabolism 199377 1419-1422.

57 Gicquel C, Dib A, Bertagna X, Amselem S \& Le Bouc Y. Oncogenic mutations of alpha-Gi2 protein are not determinant for human adrenocortical tumorigenesis. European Journal of Endocrinology $1995133166-172$.

58 Reincke M, Mora P, Beuschlein F, Arlt W, Chrousos GP \& Allolio B. Deletion of the adrenocorticotropin receptor gene in human adrenocortical tumors: implications for tumorigenesis. Journal of Clinical Endocrinology and Metabolism 199782 3054-3058.

59 Beuschlein F, Klink A, Gebauer B, Fassnacht M, Allolio B \& Reincke M. Discerning malignancy in adrenal masses: detection of loss of heterozygosity (LOH) of the ACTH receptor gene in adrenal carcinomas but not adenomas using a novel microsatellite marker within the ACTH receptor gene. In Program and Abstracts of The Endocrine Society Meeting, Toronto, ON, Canada, 21-24 June 2000, P868. Bethesda, MD, USA: The Endocrine Society Press.

Received 20 June 2000

Accepted 10 October 2000 